\title{
E. coli O157:H7 and Salmonella Species: Public Health Importance and Microbial Safety in Beef at Selected Slaughter Houses and Retail Shops in Eastern Ethiopia
}

\author{
Shimelis Mengistu ${ }^{1 *}$, Edget Abayneh² and Daniel Shiferaw ${ }^{1}$ \\ ${ }^{1}$ College of Veterinary Medicine, Haramaya University, PO Box 138, Dire Dawa, Ethiopia \\ ${ }^{2}$ Arba Minch Tsetse Fly and Trypanosomosis Investigation and Control Center, Arba Minch, Ethiopia
}

\begin{abstract}
A cross-sectional study was conducted from March 2014 to January 2015 in Dire Dawa city and Haramaya University slaughterhouses and retail shops to identify major foodborne pathogens, assess the beef microbial safety and potential contamination risk factors. 320 beef and environmental pooled samples were examined for the presence of E. coli, E. coli O157:H7 and Salmonella in accordance with international standard guidelines. On each visit of the slaughter house a total of four pooled swab samples were taken each from cleaned, disinfected and dry surfaces, other from hooks, knives and aprons, the third from personnel's hands who works on flaying, evisceration and carcass cutting before the beginning of operation. For isolation and identification of pathogens from meat, 25 gram of sample was weighed, cut in to small piece with different sterile scalpel blade and placed into sterile stomacher bags. The questionnaire survey data and laboratory results of the collected samples were entered into databases using Micro-Soft Excel computer program and analyze using SPSS version-19.0. Of 290 total beef samples collected, E. coli was isolated from 36(12.41\%) and of which 6(2.06\%) were confirmed on Sorbitol MacConkey agar to be E. coli $\mathrm{O} 157 \mathrm{H7}$. On the other hand $8(2.75 \%)$ Salmonella spp. was identified using culture and biochemical tests. The present study indicated significantly higher fecal coliforms counts in beef samples from $\mathrm{HU}$ slaughterhouse $\left(7.50 \log 10 \mathrm{cfug}^{-1}\right)$ than in carcass sample from Haramaya retail shop $\left(4.80 \log 10 \mathrm{cfug}^{-1}\right)$. Out of 30 environmental pooled samples, E. coli, E. coli O157: $\mathrm{H} 7$ and Salmonella were investigated in $7(23.33 \%), 2(6.66 \%)$ and $2(6.66 \%)$, respectively. From the visual observations: slaughterhouse, hygienic practice employed, personnel habit were found below the minimum standards. Therefore, good management and hygienic practices should be introduced in order to enhance the overall safety and hygienic quality of beef for the safeguard of consumers.
\end{abstract}

Keywords: APC; Beef; E. coli; E. coli O157:H7; FCC; Salmonella; Slaughterhouse

\section{Introduction}

Foodborne pathogens are one of the leading causes of illness and death in the world. They place heavy burden costing billions of dollars in medical care, social costs and overall economic and infrastructure effects of countries [1]. It mostly affects developing countries, due to major contributing factors such as overcrowding, poverty, changes in eating habits, mass catering, complex and lengthy food supply procedures with increased international movement, inadequate sanitary conditions and poor general hygiene practices $[2,3]$. In developing countries including Ethiopia up to 2 million people die per year due to disease of foodborne pathogens [4]. Over the last 20 years, the emergence of major foodborne pathogens such as Salmonella and E. coli have persisted as a major public health concerns and provide clear examples of the persistence of foodborne pathogens despite considerable efforts aimed at prevention and control [5].

Meat processing at retail level is likely to contribute for the higher levels of contamination in minced beef as compared to carcasses. The presence of even small numbers of pathogens in meat and edible offal may lead to heavy contamination of minced meat when it is cut into pieces and the surface area of the meat increases; as more microorganisms are added to the surfaces of exposed tissue [6]. Previous studies conducted in many parts of the country indicated the occurrence of pathogens including Salmonella in different food animals, meat and meat products. In addition, outbreaks of infections related with poor hygiene and consumption of contaminated food were reported in Ethiopia where some were by Salmonella and E. coli [7-9].
In Ethiopia, the widespread habit of raw beef consumption is a potential cause for foodborne illnesses besides the common factors such as overcrowding, poverty, inadequate sanitary conditions and poor general hygiene [7]. Raw meat is available in open-air local retail shops without appropriate temperature control and this is purchased by households and also minced meat (Kitfo) is served as raw, slightly-cooked or well-cooked in Dire Dawa administrative city and Haramaya University. Therefore, the main objectives of this study were to determine the microbial safety of beef through isolation and identification of foodborne bacterial pathogens, assess potential sources of beef contamination, investigate hygienic conditions, practices and hygienic quality of beef in slaughterhouses and retail meat shops.

\section{Materials and Methods}

\section{Study area and population}

The study was conducted at slaughterhouse and ten retail shops

*Corresponding author: Shimelis Mengistu, College of Veterinary Medicine Haramaya University, PO Box 138, Dire Dawa, Ethiopia, Tel: +251925920594 E-mail: shimemenge@yahoo.com

Received August 16, 2017; Accepted August 31, 2017; Published September 01, 2017

Citation: Mengistu S, Abayneh E, Shiferaw D (2017) E. coli O157:H7 and Salmonella Species: Public Health Importance and Microbial Safety in Beef at Selected Slaughter Houses and Retail Shops in Eastern Ethiopia. J Vet Sci Technol 8: 468. doi: 10.4172/2157-7579.1000468

Copyright: (c) 2017 Mengistu S, et al. This is an open-access article distributed under the terms of the Creative Commons Attribution License, which permits unrestricted use, distribution, and reproduction in any medium, provided the original author and source are credited. 
in Dire dawa administrative city and in slaughterhouse and one retail meat shop in Haramaya University from March 2014 to January 2015. Cattle, camel, sheep and goats were the main animals slaughtered at Dire dawa municipal abattoir and additionally small ruminants were also slaughtered at different hotels and restaurants in the city. On the other hand, cattle are the only animal slaughtered at Haramaya University slaughterhouse for students' (cafeteria) and staff lounge consumptions.

\section{Study protocol}

A cross-sectional study was conducted to determine the microbial safety and hygienic quality of beef samples drawn from municipal slaughterhouse and retail meat shops. In addition checklist and interview were made on food handlers working at food establishment, to determine the hygienic status of the premises and safety practices of meat handlers. In the present study beef samples and environmental pooled samples were collected from slaughterhouses and retails shops in both study areas.

Semi-structured questionnaire was developed and distributed for 50 slaughterhouse workers to assess their understanding and knowledge in handling meat safely, personnel practices regarding prohibited habits and actions, personnel hygiene and educational backgrounds. The abattoir visit and direct assessment was also conducted to support questionnaires in testing the hygienic and sanitation practices employed at the slaughterhouses.

\section{Sample size determination}

The sample size required for this study was determined according to [10] by taking $5.6 \%$ and $3 \%$ previous prevalences for Salmonella and E. coli O157:H7 at Dire Dawa [11] and HU [12] respectively; assuming that the slaughter animals had come from the same origin in both study areas. Accordingly, 81 beef samples from slaughterhouse and the other 81 from 10 randomly selected retails shops (from 542 total retails shops) in Dire Dawa. However, to increase precision of the study, sample size was increased by 1.23 folds and a total 290 beef sample (200 from dire dawa and 90 from $\mathrm{HU}$ ) were collected. Additionally, 30 environmental pooled samples (from equipment, surface, workers hands, vehicles and etc.) were collected during the study (Table 1).

\section{Sample collection and laboratory techniques procedures}

The microbial safety and hygiene quality were then assayed by using the methods recommended by International Commission on Microbiological Specifications for roods [13]. All the samples were investigated with respect to Salmonella, E. coli and E. coli O157:H7 detection and aerobic plate and fecal coliforms counts.

On each visit of the slaughter house a total of four pooled swab samples were taken each from cleaned, disinfected and dry surfaces, other from hooks, knives and aprons, the third from personnel's hands who works on flaying, evisceration and carcass cutting before the beginning of operation. The fourth from the surface of transporting vehicles by rubbing thoroughly with a moistened swab. The pooled environmental sample collections were conducted two times within three months. In each visit of each retail shops a total of three pooled swab samples were taken each from cutting boards and meat grinder, other from hooks, knives and protective cloth. the third sample from personnel's hands (butcher men) before the start of their routine work, by rubbing thoroughly with a moistened swab. The samples were then returned to a test tube containing $9 \mathrm{ml}$ sterile buffered peptone water (BPW). All samples were transported to the Microbiology Laboratory of College of Veterinary Medicine, HU using ice box on ice packs and then the samples were analyzed upon arrival and sometimes within 24 hours of sampling.

For isolation and identification of pathogens from meat, 25 gram of sample was weighed, cut in to small piece with different sterile scalpel blade and placed into sterile stomacher bags. And then the sample was diluted with $225 \mathrm{ml}$ of sterile BPW and homogenized in a stomacher at $230 \mathrm{R}$ for 2 minutes [14]. In case of environmental samples; pooled swab samples were placed into a test tubes that contained $9 \mathrm{ml}$ sterile BPW. Subsequently, 10 -fold serial dilutions were made to $10^{-6}$ for spreadplating. Samples were analyzed for the presence of E. coli O157:H7 and Salmonella spp. by employing standard guidelines. The E. coli O157:H7 detection was carried out according to the protocol of ISO 16654, 2001 standard. For isolation and identification Esherchia coli O157:H7 does not ferment sorbitol and, therefore, produces colorless colonies. In contrast, most other $E$. coli strains ferment sorbitol and form pink colonies and Latex E. coli $\mathrm{O} 157: \mathrm{H} 7$ agglutination test was performed to determine strains. The procedures for isolation of Salmonella from food were based on protocol of the ISO 6579, 2002 standard. Salmonella was isolated from beef sample ( $25 \mathrm{~g})$ homogenized in 225 $\mathrm{mL}$ of $0.1 \%$ buffered peptone water (BPW) (HiMedia, India). Aliquot $(1 \mathrm{ml})$ was added to $10 \mathrm{~mL}$ of Rappaport Vassiliadis (Oxoid, England) [15]. Following this procedure, eventually two even more colonies from pure isolate were inoculated on urea broth (SRL, India) and incubated at $37^{\circ} \mathrm{C}$ for 24 hours. All test tubes that were urease negative were treated as suspects of Salmonella. In addition isolate that was Gram-negative rod, methyl red and citrate positives but oxidase indole and voges-proskauer negatives which are non-lactose and sucrose fermenting were accepted putatively as Salmonella $[16,17]$.

The aerobic plate count (APC) were enumerated using plate count agar (APC); twenty five grams of beef sample was weighed and homogenized in $225 \mathrm{~mL}$ of $0.1 \%$ sterile peptone water using a sterile homogenizeras described in [15]. In this study fecal coliforms were also employed using violet red bile agar (VRBL); 25 gram of beef sample was weighed and homogenized in $225 \mathrm{~mL}$ of $0.1 \%$ sterile peptone water using a sterile homogenizer. From the 10 -fold dilutions of the homogenates, $0.1 \mathrm{~mL}$ of $10^{-4}, 10^{-5}$ and $10^{-6}$ dilutions of the homogenates were spread on to agar plates. Finally, on the VRBL medium, pale colonies with greenish zones reflect lactose fermentation by fecal coliforms, which appear slowly [18].

\section{Statistical analysis}

The data collected through questionnaire survey and laboratory results of the collected samples were entered into databases using Micro-Soft Excel computer program and analyze using SPSS version-19.0. Descriptive statistics were used to describe the nature and the characteristics of the questionnaire survey result. The aerobic bacterial and fecal coliform counts were expressed as mean using excel and compared by ANOVA. A Chi-Square test was applied to examine whether the differences between the values and the level of contamination between slaughterhouse and retail shops and associated risk factor were significant. A p-value of less or equal to 0.05 and chisquare value were considering indicative of a statistically significant difference.

\section{Results}

Isolation of bacteria from beef slaughtered and marketed at Dire Dawa city and Haramaya university

Out of 90 beef samples from $\mathrm{HU}$ (45 beef samples from 
slaughterhouse and 45 beef samples from retail shop) examined bacteriologically $21(23.3 \%), 1(1.1 \%)$ and $6(6.7 \%)$ had E. coli, E. coli O157:H7 and Salmonella spp. respectively. None of the 90 beef samples from HU had mixed bacterial contamination.

Out of 200 beef samples from Dire Dawa (100 beef samples from slaughterhouse and 100 from ten randomly selected retail shops) examined bacteriologically, 15(7.5\%), 5(2.5\%) and 2(1\%) had E. coli, E. coli O157:H7 and Salmonella spp., respectively. One of the 200 samples of beef had yielded both groups of bacteria. The prevalence of $E$. coli, E. coli O157:H7 and Salmonella in Dire dawa slaughterhouse and retail shop were presented in Table 2.

\section{Hygienic quality of beef from Dire Dawa and $\mathrm{HU}$ slaughterhouses and retail shops}

The results of total Aerobic bacteria (AB) in beef by using detection methods are summarized in Table 3. The total beef $A B$ was $27 / 290$ (9.31\%) from slaughterhouse and retail shops. In this study, fecal coliforms (FC) were detected and enumerated irrespective of pathogenicity of the strain to estimate the level of hygiene. Out of 290 samples, FC were present in $11(3.79 \%)$ of which $8(17.77 \%)$ and $2(2 \%)$ were found in $\mathrm{HU}$ and Dire dawa slaughterhouses, respectively (Table $3)$.

Results of mean APCs of beef in this study are presented in Table 4. Fecal coliforms count (FCC) in beef indicates the hygienic qualities of meat.

\section{Major source of microbial contamination for beef from slaughterhouse and retail shops}

It is generally accepted that microbial loads on surfaces and equipment vary in different food plants depending on the microbial

Average microbial load for APCs and FCCs in beef contact surfaces at slaughterhouse and retail shops are shown in Table 5. In current study Total Aerobic Bacteria in different sample groups in retail shop (knives and hooks, cutting boards and personnel hands), were examined. Out of 30 environmental pooled samples $(8,8,8$ and 6 were from HU slaughterhouse, HU retail shop, Dire dawa slaughterhouse and Dire dawa retail shops respectively; out of 10 randomly selected retail shops due to the fact that 7 of the selected retail shops could not be voluntary to take swab sample), E. coli, E. coli $\mathrm{O} 157: \mathrm{H} 7$ and Salmonella was present in 7(23.33\%), 2(6.66\%) and 2(6.66\%) samples. The occurrence of E. coli, E. coli O157:H7 and Salmonella spp. in beef quality of the food [19].

contact surfaces from slaughterhouses and retail shops are summarized in Table 6.

Fecal coliforms counts in different sample groups in retail shops and slaughterhouse (knives and hooks, cutting boards, personnel hands and transporting vehicle), were examined. The result varied from $3.11 \log 10 \mathrm{cfu} / \mathrm{cm}^{2}-7.20 \log 10 \mathrm{cfu} / \mathrm{cm}^{2}$ in knives and hooks, cutting boards, balance, personnel hand and transport vehicle at slaughterhouse and retail shops. The overall mean of coliforms count in retail shops environment was $5.40 \log 10 \mathrm{cfu} / \mathrm{cm}^{2}$ and $2.38 \log 10$ $\mathrm{cfu} / \mathrm{cm}^{2}$ in slaughterhouse. Furthermore, the result of aerobic plate counts and coliform count were compared by ANOVA showed that there is significant $(\mathrm{P} \leq 0.01)$ variation in the means of fecal coliforms count found in different meat contact surfaces in retail shop and slaughterhouse.

\section{Hygienic practices in Dire Dawa and hu slaughterhouses and retail shops}

According to Abattoir, Cutting and Packing Plant Standard [20], abattoir wall, floors, ceilings, windows, doors, lighting, airconditioning/ventilation, services and equipment must be constructed to withstand and facilitate thorough cleaning and minimize contamination of product, either through pests, harboring of dirt or other physical, chemical or microbiological hazards.

In Dire dawa slaughterhouse except in Muslim slaughter premises, it is well organized beef slaughterhouse than HU slaughterhouse, In Dire dawa slaughterhouse for Christian have clear division of slaughtering process into stunning, bleeding, skinning and evisceration, whereas in Muslim slaughter premises and HU slaughterhouse no clear division existed. In both slaughterhouses, horizontal bleeding on killing floor was conducted, however, only vertical dressing process on overhead rail procedure was conducted in Dire dawa slaughterhouse.

The visual observation result in HU slaughterhouses indicated that the animal brought to slaughterhouse without prior antemortem inspection was done and without fasting the animal for 12 to 24 hours before slaughter which increases the micro floral load and sometimes the animal brought to slaughterhouse immediately after arrival from market results in shading of microorganisms. But in Dire dawa slaughterhouse the pre-slaughter procedure was done 12 hours before the slaughtering process presided. The animal also encountered stressful handling during riding on foot from the HU farm to $\mathrm{HU}$ slaughter house in the night sometimes they even suffered fracture and excitement. Beside these, stunning process was done by kicking using the back of axe and most of the time the workers couldn't made

\begin{tabular}{|c|c|c|c|}
\hline No & Sample type & Sample collected area & Total sample \\
\hline 1 & Raw beef meat & $\begin{array}{l}45 \text { from HU slaughter house } \\
45 \text { from HU retail shop } \\
100 \text { from DD slaughter house } \\
100 \text { from DD retail shop }\end{array}$ & 290 \\
\hline 2 & $\begin{array}{c}\text { Environmental sample } \\
\text { Equipment } \\
\text { Workers hand } \\
\text { Contact surface } \\
\\
\text { Balance } \\
\text { Vehicle }\end{array}$ & $\begin{array}{c}2 \text { from each of the four site } \\
2 \text { from each of the four site } \\
2 \text { from each } H U \text { and DD slaughter houses } \\
2 \text { from } H U \text { retail shop } \\
2 \text { from each } H U \text { and DD slaughter houses } \\
2 \text { from each HU and DD retail shops }\end{array}$ & 30 \\
\hline 3 & $\begin{array}{l}\text { Cutting board and table } \\
\text { Respondents }\end{array}$ & $\begin{array}{l}22 \text { respondents from } \mathrm{HU} \\
28 \text { respondents from DD }\end{array}$ & 50 \\
\hline
\end{tabular}

$\mathrm{HU}=$ Haramaya University; DD=Dire Dawa

Table 1: Summary of the type and total amount of samples collected from the study areas. 
Citation: Mengistu S, Abayneh E, Shiferaw D (2017) E. coli O157:H7 and Salmonella Species: Public Health Importance and Microbial Safety in Beef at Selected Slaughter Houses and Retail Shops in Eastern Ethiopia. J Vet Sci Technol 8: 468. doi: 10.4172/2157-7579.1000468

Page 4 of 8

\begin{tabular}{|c|c|c|c|}
\hline \multirow{2}{*}{ Samples source } & Number of Samples Processed & \multicolumn{2}{|c|}{ Bacterial Isolates (\%) } \\
\cline { 2 - 4 } & 45 & $16(35.6 \%)$ & E.coli O157:H7 \\
\hline HU slaughterhouse & 45 & $5(11.1 \%)$ & $1(2.2 \%)$ \\
\hline HU retail shop & 100 & $9(9 \%)$ & $0(0 \%)$ \\
\hline DD slaughterhouse & 100 & $6(6 \%)$ & $4(4 \%)$ \\
\hline DD retail shops & $\mathbf{2 9 0}$ & $\mathbf{3 6}(12.41 \%)$ & $1(1 \%)$ \\
\hline Total & & $\mathbf{6}(2.06 \%)$ \\
\hline
\end{tabular}

$\mathrm{P} \leq 0.01, \mathrm{df}=3$ for $E$. coli, $\mathrm{P}>0.05, \mathrm{df}=3$ for $E$. coli $\mathrm{O} 157: \mathrm{H} 7$ and Salmonella

Table 2: Frequency of bacterial isolate of beef samples from Dire Dawa and HU slaughterhouse and retail shops.

\begin{tabular}{|c|c|c|}
\hline Sample source & No of sample & \multicolumn{2}{|c|}{ Organisms detected } & No (\%) AB \\
\hline HU slaughter house & 45 & $6(13.33)$ \\
\hline HU retail shop & 45 & $8(17.77)$ \\
\hline DD slaughter house & 100 & $10(10)$ \\
\hline DD retail shops & 100 & (17.77) \\
\hline Total & $\mathbf{2 9 0}$ & $\mathbf{2 ( 2 )}$ \\
\hline
\end{tabular}

$\mathrm{FCs}=$ Fecal coliforms, $\mathrm{AB}=$ Aerobic bacteria; $\mathrm{P}>0.05$, $\mathrm{df}=1$

Table 3: Indicator organisms detected from beef sampled from HU and Dire Dawa slaughterhouse and retail shops.

\begin{tabular}{|c|c|c|c|c|c|c|c|}
\hline \multirow{3}{*}{ Sample Source } & \multirow{3}{*}{ No of Sample } & \multicolumn{6}{|c|}{ Bacterial colonies $\log 10$ cfug $^{-1}$} \\
\hline & & \multicolumn{3}{|c|}{ APCs } & \multicolumn{3}{|c|}{ FCCs } \\
\hline & & Mean & Min & Max & Mean & Min & Max \\
\hline HU slaughter house & 45 & 7.11 & 4.00 & 8.80 & 7.50 & 3.60 & 9.20 \\
\hline HU retail shop & 45 & 2.30 & 4.10 & 8.80 & 4.80 & 0.00 & 5.70 \\
\hline DD slaughter house & 100 & 5.63 & 0.30 & 8.80 & 1.13 & 0.33 & 4.89 \\
\hline DD retail shop & 100 & 3.10 & 6.72 & 9.73 & 0.00 & 0.00 & 0.00 \\
\hline
\end{tabular}

FCCs=Fecal coliform counts, APCs=Aerobic plate counts; $P \leq 0.01, \mathrm{df}=1$

Table 4: Microbial loads of indicator organisms on beef in $\mathrm{HU}$ and Dire dawa slaughterhouse and retail shops.

\begin{tabular}{|c|c|c|c|c|c|c|c|}
\hline \multirow{3}{*}{ Sources } & \multirow{3}{*}{ No of Sample } & \multicolumn{6}{|c|}{ Enumerated organisms $\log 10 \mathrm{cfu} / \mathrm{m}^{2}$} \\
\hline & & \multicolumn{3}{|c|}{ APCs } & \multicolumn{3}{|c|}{ FCCs } \\
\hline & & Mean & Min & Max & Mean & Min & Max \\
\hline \multicolumn{8}{|l|}{ HU slaughterhouse } \\
\hline Equipments & 2 & 3.05 & TFC & 6.10 & TFC & TFC & TFC \\
\hline Surfaces & 2 & TFC & TFC & TFC & TFC & TFC & TFC \\
\hline Workers hands & 2 & TFC & TFC & TFC & TFC & TFC & TFC \\
\hline Vehicle & 2 & TFC & TFC & TFC & TFC & TFC & TFC \\
\hline \multicolumn{8}{|l|}{ HU Retail shops } \\
\hline Equipments & 2 & TFC & TFC & TFC & 5.38 & 5.10 & 5.67 \\
\hline Cutting boards & 2 & TFC & TFC & TFC & 4.78 & 4.24 & 5.33 \\
\hline Workers hands & 2 & TFC & TFC & TFC & 5.06 & 4.50 & 5.63 \\
\hline Balance & 2 & TFC & TFC & TFC & TFC & TFC & TFC \\
\hline \multicolumn{8}{|l|}{ DD slaughterhouse } \\
\hline Equipment & 2 & TFC & TFC & TFC & 4.43 & 3.11 & 5.76 \\
\hline Surface & 2 & TFC & TFC & TFC & 4.42 & 3.20 & 5.65 \\
\hline Worker hand & 2 & TFC & TFC & TFC & 4.32 & 3.32 & 5.32 \\
\hline Vehicle & 2 & 5.73 & 4.56 & 6.91 & 5.87 & 4.54 & 7.20 \\
\hline \multicolumn{8}{|l|}{ DD retail shops } \\
\hline Equipment & 2 & TFC & TFC & TFC & 4.96 & 4.32 & 5.61 \\
\hline Cutting board & 2 & TFC & TFC & TFC & 6.26 & 5.65 & 6.88 \\
\hline Worker hand & 2 & TFC & TFC & TFC & 5.98 & 4.87 & 7.1 \\
\hline
\end{tabular}

TFC=Too Few to Count, $P \leq 0.01, \mathrm{df}=1$,

Table 5: Microbial loads of indicator organisms on beef contact surfaces from HU and Dire Dawa slaughterhouse and retail shops.

stunning by a single kick rather they kick several times which result the animal to suffering from pain. In general, the pre-slaughtering process in HU slaughterhouse brought the animal to stress which facilitate the rapid multiplication and shading of E. coli O157:H7 and Salmonella spp. this could be one of the source of contamination of meat. The hygienic and sanitation practices employed at the study areas are summarized in Table 7.

Hands are rarely free from microorganisms. It is of the utmost importance that soap (preferably in a dispenser) and hot running water 
are used for this purpose, thus aiming to reduce the microbiological load on hands $[21,22]$ suggested that soap and hot water, at $45^{\circ} \mathrm{C}$, should always be available at the washing-basins. [21] recommend that hand-washing alone has no effect on the reduction of bacteria on hands; it depends on the mechanical action, the duration and the type of soap and sanitizers being used.

It is important to know the educational background, type and terms of employment in the abattoir, and how the meat handler acquired their skills to establish their knowledge in handling meat safely. Accordingly hygienic quality of beef had significantly associated $(\mathrm{p}=0.001)$ with educational status of meat handler's, fecal coliform organisms in meat were more likely prevalent in slaughter house handled by poor knowledge and low level educational status food handler's. The knowledge and educational level of personnel working in both food establishments are summarized in Table 8.

In this study, personnel practices regarding prohibited habits and actions were also assessed. The visual observations indicated that, fraudulent activity and habits like eating, chewing and smoking in the slaughterhouse by the workers were common practices in both slaughterhouses especially prominent in Dire dawa slaughterhouse while they were on duty of meat processing. The overall result regarding habit, personnel cloth and cleanness in both slaughterhouses was summarized in Table 9.

\section{Discussions}

The occurrence of $E$. coli in meat samples from HU slaughterhouse in this study was in close agreement with the result of [12] who isolated E. coli in $30.97 \%$ of the meat samples studied in the same slaughterhouse. The present result is much lower than the finding of [23] who isolated E. coli in $91.4 \%$ of meat samples from abattoir in Mekelle.

Generally, the high prevalence of $E$. coli in the meat samples from HU slaughterhouse indicated the contamination of meat with intestinal content since evisceration take place in the same place. There was a significant difference in the prevalence of $E$. coli between HU slaughterhouse and Dire Dawa slaughterhouse $(\mathrm{P} \leq 0.01)$. This difference could be due to difference in hygienic condition and practice in both slaughterhouses.
The prevalence of E. coli O157:H7 isolated from beef in $\mathrm{HU}$ slaughterhouse $(2.2 \%)$ and Dire dawa slaughterhouse (4\%) in this study was in agreement with the reported prevalence of $2.60 \%$ [23] and $2.65 \%$ [12] in Ethiopia. There was no statistically significant difference in the prevalence of $E$. coli O157:H7 between HU slaughterhouse and Dire dawa slaughterhouse $(\mathrm{P}>0.05)$.

In comparison to the present study, a higher prevalence of $E$. coli O157:H7 were reported from different countries; $8 \%$ in Debre Zeit and Mojo [24] and $8.1 \%$ in Mojo, Ethiopia [25], 9\% in India [26]. In the current study, lower prevalence of E. coli O157:H7 was also isolated from Dire Dawa retail shop (1\%) which is in agreement with the report from America (0.8\%) [27] and Kenya (0.2\%) [28].

The frequency of isolation of Salmonella spp. in meat samples in this study was $6.7 \%$ from both HU slaughterhouse and retail shop. This result was in agreement with $5.6 \%$ prevalence reported from muscle in Addis Ababa, Debre Zeit, Dire dawa and Jigjiga [11], 8.5\% from minced beef in Addis Ababa [29] and 4.8\% from beef in Bahir Dar [30].

The detection of $6.7 \%$ of Salmonella in beef in HU slaughterhouse and retail shop as compared to Dire dawa slaughterhouse and retail shops (1\%) suggests that the process of evisceration could be the main source of carcass contamination in addition to carrier state. Crosscontamination can also occur during the skinning process as a result of poor hygienic conditions. The other probable source of contamination is infected abattoir personnel. When comparing with the present study a relatively high prevalence of Salmonella (14.4\%) was reported by [6] from minced beef in Addis Ababa. It was also lower than the $40 \%$ prevalence reported by [31]. Similarly, [32] reported Salmonella contamination rate of $42 \%$ from minced meat (locally known as «kitfo») samples collected from different hotels, bars and restaurants in Addis Ababa.

Presence of microbes in high numbers (APC $>5 \log \mathrm{cfu} / \mathrm{cm}^{2}$ or $\mathrm{g}^{-1}$ ) fast tracks the spoilage of the meat. According to the international standard organization [33].

APC of $80 \%$ of analyzed samples must not exceed $5 \log$ cfug $^{-1}$ or $\mathrm{cm}^{2}$, whereas $20 \%$ of the samples may have counts of up to $5 \mathrm{log} \mathrm{cfug}^{-1}$ or $\mathrm{cm}^{2}$ [34]. In this study $5.8 \%$ of samples had APCs more than 5.00

\begin{tabular}{|c|c|c|c|c|c|}
\hline & & \multirow{3}{*}{$\begin{array}{c}\text { No of sample } \\
2\end{array}$} & \multicolumn{3}{|c|}{ Bacterial detected } \\
\hline \multicolumn{2}{|c|}{ Sources } & & $\begin{array}{l}\text { No }(\%) \\
\text { E. coli }\end{array}$ & No (\%) E. coli 0157H7 & No (\%) Salmonella \\
\hline \multirow[t]{4}{*}{ HU slaughterhouse } & Equipments & & $2(100)$ & $1(50)$ & $0(0)$ \\
\hline & Surfaces & 2 & $1(50)$ & $0(0)$ & $0(0)$ \\
\hline & Workers hands & 2 & $1(50)$ & $0(0)$ & $0(0)$ \\
\hline & Vehicle & 2 & $0(0)$ & $0(0)$ & $0(0)$ \\
\hline \multirow[t]{4}{*}{ HU Retail shops } & Equipments & 2 & $0(0)$ & $0(0)$ & $1(50)$ \\
\hline & Cutting boards & 2 & $1(50)$ & $0(0)$ & $0(0)$ \\
\hline & Workers hands & 2 & $0(0)$ & $0(0)$ & $0(0)$ \\
\hline & Balance & 2 & $0(0)$ & $0(0)$ & $0(0)$ \\
\hline \multirow[t]{4}{*}{ DD slaughterhouse } & Equipment & 2 & $1(50)$ & $0(0)$ & $1(50)$ \\
\hline & Surface & 2 & $0(0)$ & $0(0)$ & $0(0)$ \\
\hline & Worker hand & 2 & $0(0)$ & $0(0)$ & $0(0)$ \\
\hline & Vehicle & 2 & $1(50)$ & $1(50)$ & $0(0)$ \\
\hline \multirow[t]{4}{*}{ DD retail shops } & Equipment & 2 & $0(0)$ & $0(0)$ & $0(0)$ \\
\hline & Cutting board & 2 & $0(0)$ & $0(0)$ & $0(0)$ \\
\hline & Worker hand & 2 & $0(0)$ & $0(0)$ & $0(0)$ \\
\hline & Total & 30 & $7(23.33)$ & $2(6.66)$ & $2(6.66)$ \\
\hline
\end{tabular}

$p>0.05, d f=3$

Table 6: Bacterial species detected from beef contact surfaces sampled from HU and Dire Dawa slaughterhouse and retail shops. 
Citation: Mengistu S, Abayneh E, Shiferaw D (2017) E. coli O157:H7 and Salmonella Species: Public Health Importance and Microbial Safety in Beef at Selected Slaughter Houses and Retail Shops in Eastern Ethiopia. J Vet Sci Technol 8: 468. doi: 10.4172/2157-7579.1000468

Page 6 of 8

\begin{tabular}{|c|c|c|}
\hline Practices & Dire Dawa & HU \\
\hline \multicolumn{3}{|l|}{ Cleaning and disinfection of knives and hooks } \\
\hline Before the commencement of work & $28(100 \%)$ & $21(95.5 \%)$ \\
\hline When excessively and visibly soiled & & $1(4.5 \%)$ \\
\hline \multicolumn{3}{|l|}{ Manner of cleaning and disinfection } \\
\hline Using detergents and water & $22(78.6 \%)$ & $21(95.5 \%)$ \\
\hline Rinsing with water only & $6(21.4 \%)$ & $1(4.5 \%)$ \\
\hline \multicolumn{3}{|l|}{ Floor Surface cleaning and disinfection } \\
\hline Before commencement of work & $28(100 \%)$ & $20(90.9 \%)$ \\
\hline When excessively and visibly soiled & & $1(4.55 \%)$ \\
\hline After commencement of work & & $1(4.55 \%)$ \\
\hline \multicolumn{3}{|l|}{ Manner of cleaning and disinfection of surface } \\
\hline Using detergents and water & $10(35.7 \%)$ & $15(68.2 \%)$ \\
\hline Rinsing with water only & $18(64.3 \%)$ & $7(31.8 \%)$ \\
\hline \multicolumn{3}{|l|}{ Hand washing before starting handling raw meat } \\
\hline Yes & $28(100 \%)$ & $22(100 \%)$ \\
\hline \multicolumn{3}{|l|}{ Manner of hand washing } \\
\hline Using detergents and water & $27(96.4 \%)$ & $17(77.3 \%)$ \\
\hline Rinsing with water only & $1(3.6 \%)$ & $5(22.7 \%)$ \\
\hline \multicolumn{3}{|l|}{ Presence of sanitary regulatory system } \\
\hline Yes & $2(7.1 \%)$ & 0 \\
\hline No & $26(92.9)$ & $22(100 \%)$ \\
\hline
\end{tabular}

$p \leq 0.01, d f=1$

Table 7: Hygienic and sanitation practices employed at Dire dawa and HU slaughterhouses and retail shops.

\begin{tabular}{|c|c|c|}
\hline Skills & D.D slaughterhouse frequency (\%) & HU slaughterhouse frequency (\%) \\
\hline \multicolumn{3}{|l|}{ Educational status } \\
\hline None & 0 & $1(4.55)$ \\
\hline Elementary/junior & $11(39.3 \%)$ & $13(59.1 \%)$ \\
\hline High school & $12(42.9 \%)$ & $7(31.8 \%)$ \\
\hline College & $4(14.3 \%)$ & $1(4.55 \%)$ \\
\hline Graduate & $1(3.6 \%)$ & \\
\hline \multicolumn{3}{|l|}{ Sources of meat processing skills } \\
\hline Observation & $21(75 \%)$ & $19(86.4 \%)$ \\
\hline Parents & $4(14.3 \%)$ & $3(13.6 \%)$ \\
\hline Formal training & $3(10.7 \%)$ & 0 \\
\hline
\end{tabular}

Table 8: Educational status of meat handler's.

\begin{tabular}{|c|c|c|}
\hline Prohibited habits & Dire Dawa & HU \\
\hline \multicolumn{3}{|l|}{ Jewelry } \\
\hline Worn & $19(67.9 \%)$ & $2(9.1 \%)$ \\
\hline Not worn & $9(32.1 \%)$ & $20(90.9 \%)$ \\
\hline \multicolumn{3}{|l|}{ Finger nails } \\
\hline Short and polished & $22(78.6 \%)$ & $15(68.2 \%)$ \\
\hline Short/ not polished & $6(21.4 \%)$ & $5(22.7 \%)$ \\
\hline Long and polished & & $2(9.1 \%)$ \\
\hline \multicolumn{3}{|c|}{ Smoking in meat processing plants } \\
\hline Yes & $13(46.4 \%)$ & $3(13.6 \%)$ \\
\hline No & $15(53.6 \%)$ & $19(86.4 \%)$ \\
\hline \multicolumn{3}{|l|}{ Hair cover } \\
\hline Used & $24(85.7 \%)$ & $14(63.6 \%)$ \\
\hline Not covered & $4(14.3 \%)$ & $8(36.4 \%)$ \\
\hline \multicolumn{3}{|l|}{ Gum boots } \\
\hline Used & $18(64.3 \%)$ & $22(100 \%)$ \\
\hline Not used & $10(35.7 \%)$ & 0 \\
\hline
\end{tabular}

$p \leq 0.01, d f=1$

Table 9: Practices of the meat handlers regarding prohibited habits and actions. 
$\log 10$ cfug $^{-1}$ the condition was unacceptable. Lower level of aerobic plate count in this study was much lower than previous studies [2,3537]. However, the microbial contamination level of slaughterhouse and retail shops were higher as compared to reports from developed countries and our results do not conform to EU specifications [38,39].

The higher aerobic plate count enumerated from HU slaughterhouse (7.11 $\left.\log 10 \mathrm{cfug}^{-1}\right)$, suggests an unusual high level of contamination and/or growth which was similar with [40] report. Given the hygienic status of the slaughterhouse and meat processing observed in the slaughterhouse.

The result of this study was much lower than presence of fecal coliforms in meat and meat studied by many researchers [41,42]. Other study results have also been reported for retail chicken $(50 \%$ incidence of E. coli) in Australia [43] which was much higher than the present study.

From the data of retail meats it was evident that the highest FCCs $\left(6.26 \log 10 \mathrm{cfu} / \mathrm{cm}^{2}\right)$ levels were found in the cutting boards at Dire dawa retail shop. Cutting board from HU retail shop got the smallest values of FCCs $\left(4.78 \log 10 \mathrm{cfu} / \mathrm{cm}^{2}\right)$ and in HU slaughterhouse was too few to count from knives and hooks, surface, vehicle and workers hand. Based on the data, the highest FCCs $\left(5.87 \log 10 \mathrm{cfu} / \mathrm{cm}^{2}\right)$ and APCs $\left(5.73 \log 10 \mathrm{cfu} / \mathrm{cm}^{2}\right)$ levels found in the transporting vehicle from Dire dawa slaughterhouse while the smallest values of FCCs $(4.32 \log 10 \mathrm{cfu} /$ $\mathrm{cm}^{2}$ ) found in workers hand in Dire dawa slaughterhouse and APCs was found too few to count in both slaughterhouses (Table 5).

In both slaughterhouses personnel interviewed to assess the hygienic conditions in the slaughterhouse responded that there was adequate potable water supply in the slaughterhouse. However, there is no hot water supply in all meat processing facilities. In both slaughterhouses, there were no facilities for knife sterilization and no rooms for retention of conditionally approved carcasses. Regarding latrine facility, both slaughterhouses had communal latrine which was properly placed but with poor management. There were no enough water supplies as a result, flies infestation of the facilities were observed. Hand washing is an essential component of infection control [44]. In general, both abattoirs have no mechanism of ensuring sanitation standards, proper waste disposal mechanism and vermin's and scavenger's protection mechanisms. Therefore, there are opportunities of contamination of slaughter facilities which in turn contaminate the exposed tissues of the carcass with microorganisms.

The behavior of worker and hygienic practices of retail shop in HU was relatively good as compared to Dire dawa retails shop and meat handlers do not have close contact with money and they do only cutting and weighing the meat. To get rid of germs and dirt, it is important to wash hands properly and frequently with detergents and warm water. Hands that have long nails are more difficult to clean thoroughly and can collect small pieces of debris and bacteria that do not wash off easily [45].

The clean gum boots are just as important as clean overalls, because they may also be a source of contamination. Gum boots should therefore be washed at the facility provided (washing-basins supplied with hot and cold water, liquid soap and a brush) before entering the processing room [22]. The purpose of hairnets and beard nets is twofold: to prevent loose hairs and dandruff from falling into the food and also to discourage the workers from running their fingers through their hair or scratching their scalps $[46,47]$.

\section{Conclusion}

In conclusion the results obtained from this study showed contamination sources of beef are more likely to be associated with insufficient hygienic practices and improper handling of meat in the slaughterhouse and retail shops. Floor surface, cutting boards, hooks and knives, workers hands and transporting vehicle in slaughterhouses as well as, in retail shops are potential sources of beef contamination. The study indicated that slaughterhouses and retail shops in HU and Dire Dawa could be the source of contamination of beef. HU and Dire dawa slaughterhouses and retail shops are not well structured and the working habits in the slaughterhouse are not good enough to satisfy an acceptable hygienic standard practices for slaughtering and processing of beef for human consumption. The study suggested that beef could be a significant source of foodborne pathogens for people in the study areas. Based on the findings of the present study the following recommendations are forwarded in order to guarantee the microbial quality of beef and minimize the risk of E. coli O157:H7 and Salmonellosis outbreak in Dire dawa and HU and its surrounding areas.

\section{Competing Interests}

There is no conflict of interest regarding the publication of this paper

\section{Funding}

This work was supported by Haramaya University Research Grant

\section{Acknowledgements}

We would like to extend our thanks to College of Veterinary Medicine of Haramaya University for all round supports.

\section{References}

1. Fratamico PA, Bhunia AK, Smith JL (2005) Foodborne Pathogens: Microbiology and Molecular Biology. Caister Academic Press, Wymondham, Norfolk, UK, p: 273.

2. Bhandare S, Sherikarv A, Paturkar A, Waskar V, Zende R (2007) A comparison of microbial contamination on sheep/goat carcasses in a modern Indian abattoir and traditional meat shops. Food Control 18: 854-868.

3. Podpecan B, Pengov A, Vadnjal S (2007) The source of contamination of ground meat for production of meat products with bacteria Staphylococcus aureus. Slov Vet Res 44: 25-30

4. WHO, Food safety and foodborne diseases and value chain management for food safety. "Forging links between Agriculture and Health" CGIAR on Agriculture and Health Meeting in WHO/HQ, Accessed June, 2007.

5. Diane GN, Marion K, Linda V, Erwin D, Awa AK, et al. (2010) Foodborne diseases, International Journal of Food Microbiology, vol. 139, pp. 3-15.

6. Ejeta G, Molla B, Alemayehu D, Muckle A (2004) Salmonella serotypes isolated from minced meat beef, mutton and pork in Addis Ababa, Ethiopia. Revue Méd Vét 11: 547-551.

7. Haymanot T, Alemseged A, Getenet B, Solomon GS (2010) Microbial flora and foodborne pathogens on minced meat and their susceptibility to antimicrobial agent. Ethiop J Helth Sci 20: 137-143.

8. Mache A, Mengistu Y, Cowley S (1997) Salmonella sero groups identified from adult diarrheal out-patients in Addis Ababa, Ethiopia: Antibiotic resistance and plasmid profile analysis. East Afr Med J 74: 183-187.

9. Alemseged F, Yami A, Birke W, S/Mariam Z, Worku K (2009) Investigation of Dysentery outbreak and Its causes, Jimma City South west, Ethiopia. Ethiop J Helth Sci 19: 147-154.

10. Thrusfield M (2007) Veterinary Epidemiology. 3rd edn. Blackwell Science, UK pp: 332.

11. Bayleyegn M, Daniel A, Woubit S (2003) Sources and distribution of Salmonella serotypes isolated from food animals, slaughterhouse personnel and retail meat products in Ethiopia. Ethio J Helth Dev 17: 63-70. 
Citation: Mengistu S, Abayneh E, Shiferaw D (2017) E. coli O157:H7 and Salmonella Species: Public Health Importance and Microbial Safety in Beef at Selected Slaughter Houses and Retail Shops in Eastern Ethiopia. J Vet Sci Technol 8: 468. doi: 10.4172/2157-7579.1000468

12. Taye M, Berhanu T, Berhanu Y, Tamiru F, Terefe D (2013) Study on carcass contaminating $\mathrm{E}$. coli in apparently healthy slaughtered cattle in Haramaya University slaughter house with special emphasis on E. coli O157:H7, Ethiopia. J Vet Sci Technol 4: 132

13. ICMSF (International Commission on Microbiological Specifications for Foods) (1986) Microorganisms in Foods 2. Sampling for microbiological analysis: Principle and specific application. 2nd edn. Blackwell Scientific Publications. UK, pp: 132-136.

14. ISO (International Organization for Standardization)/TS 11133-1 (2009) Microbiology of food and animal feeding stuffs. Guidelines on preparation and production of culture media. Part 1: General guidelines on quality assurance for the preparation of culture media in the laboratory.

15. https://www.fda.gov/Food/FoodScienceResearch/LaboratoryMethods/ ucm2006949.htm

16. Fawole MO, Oso BA (2001) Laboratory manual of microbiology: Revised edition. Ibadan: Spectrum books Ltd. pp: 127.

17. ISO (2017) Available from: https://www.iso.org/standard/56712.html

18. http://citeseerx.ist.psu.edu/viewdoc/download?doi=10.1.1.126.8163\&rep=rep1 \&type $=p d f$

19. Evans JA, Russell SL, James C, Corry JE (2004) Microbiological contamination of food refrigeration equipment. J Food Eng 62: 225-232.

20. ABM (Activity Based Management) (2008) Standards for Abattoir, Cutting and Packing Plant. Version 4.0 January, 2008 Northern Ireland.

21. Desmarchelier PM, Higgs GM, Mills L, Sullivan AM, Vanderlinde PB (1999) Incidence of coagulase positive Staphylococcus on beef carcasses in three Australian abattoirs. Int J Food Microbiol 47: 221-229.

22. Van Zyl AP (1995) Manual for the abattoir industry. 1st edn. Pretoria: Red Meat Abattoir Association 1: 123-156.

23. Mekonnen H, Habtamu T, Kelali A, Shewit K (2012) Food safety knowledge and practices of abattoir and butchery shops and the microbial profile of meat in Mekelle City, Ethiopia. Asian Pac J Trop Biomed 12: 952-957.

24. Hiko A, Asrat D, Zewde G (2008) Occurrence of $E$. coli O157:H7 in retail raw meat products in Ethiopia. J Infect Dev Ctries 2: 389-393.

25. Mersha G, Asrat D, Zewde BM, Kyule M (2009) Occurrence of E. coli O157:H7 in faeces, skin and carcasses from sheep and goats in Ethiopia. Lett Appl Microbiol 50: 71-76.

26. Luga I, Akombo PM, Kwaga JKP, Umoh VJ, Ajogi I (2007) Sero-prevalence of Faecal Shedding of E. coli O157:H7 from Exotic Dairy Cattle in North-Western Nigeria. Niger Vet J 28: 6-11.

27. Desenclos JC, Zergabachew A, Desmoulins B, Chouteau L, Desve G (1988) Clinical, microbiological and antibiotic susceptibility patterns of diarrhoea in Korem, Ethiopia. J Trop Med Hyg 91: 296-301.

28. Chapman PA, Siddons CA, Cerdan Malo AT, Harkin MA (2000) A one yea study of E. coli $\mathrm{O} 157$ in raw beef and lamb products. Epidemiol Infect 124: 207-213.

29. Zewdu E, Cornelius $P$ (2009) Antimicrobial resistance pattern of Salmonella serotypes isolated from food items and personnel in Addis Ababa, Ethiopia. Trop Anim Health Prod 41: 241-249.
30. Sefinew A, Bayleyegn M (2012) Prevalence and antimicrobial resistance profiles of Salmonella enteric serovars isolated from slaughtered cattle in Bahir Dar, Ethiopia. Trop Anim Health Prod 44: 595-600.

31. Tadesse G, Gebremedhin EZ (2015) Prevalence of Salmonella in raw anima products in Ethiopia: a meta-analysis. BMC Res Notes 8: 163.

32. Tegegne M, Ashenafi M (1998) Microbial load and incidence of Salmonella species in kitfo", traditional Ethiopian spiced, minced meat dish. Ethiop J Health Dev 12: 135-140.

33. ISO-4833-1 (2013) Available from: https://www.iso.org/obp/ ui/\#!iso:std:59509:en

34. Mukhopadhyay HK, Pillai RM, Pal UK, Kumar VJA (2009) Microbial quality of fresh chevon and beef in retail Outlets of pondicherry. Tamilnadu J Vet Anim Sci 5: 33-36.

35. Alvarez-Astorga M, Capita R, Alonso-Calleja C, Moreno B, Del M, et al (2002) Microbiological quality of retail chicken by-products in Spain. Meat Sci 62: 45-50.

36. Haque MA, Siddique MP, Habib MA, Sarkar V, Chou KA (2008) Evaluation of sanitary quality of goat meat obtained from slaughter yards and meat stalls at late market hours. Bangl J Vet Med 6: 87-92.

37. Hassan AN, Farooqui A, Khan A, Khan Y, Kazmi SU (2010) Microbial contamination of raw meat and its environment in retail shops in Karachi, Pakistan. J Infect Dev Ctries 4: 382-388.

38. Gill CO, Bryant J, Brereton DA (2000) Microbiological conditions of sheep carcasses from conventional or inverted dressing processes. J Food Prot 63 . 1291-1294.

39. Duffy EA, Belk KE, Sofos JN, LeValley SB, Kain ML, et al. (2001) Microbia contamination occurring on lamb carcasses processed in the United States. J Food Prot 64: 503-508.

40. Gill CO (2007) Sampling of red meat. In Microbiological Analysis of red meat poultry and eggs. Mead GC. Cambridge, England, Woodhead Publishing Limited. pp: 132-135.

41. Doyle ME (2007) Microbial food spoilage -Losses and control strategies. A brief review of the Literature, FRI Briefings (www.wisc.edu/fri/). Accessed December, 2012

42. Adu-Gyamfi A, Torgby-Tetteh W, Appiah V (2012) Microbiological quality of chicken sold in Accra and determination of D10-Value of E. coli. Food Nutr Sci 3. 693-698.

43. Pointon A, Sexton M, Dowsett P, Saputra T, Kiermeier A, et al. (2008) A baseline survey of the microbiological quality of chicken portions and carcasses at retail in two Australian states (2005 to 2006). J Food Prot 71: 1123-1134.

44. Larson E, Aiello A, Lee LV, Della-Latta P, Gomez-Duarte C, et al. (2003) Shor and long term effects of hand washing with antimicrobial or plain soap in the community. J Community Health 28: 139-150

45. Trickett $\mathrm{J}$ (1997) Food hygiene for food handlers. London: Macmillan Press 15: 19-27.

46. Educational Foundation of the National Restaurant Association (1992) Applied food service sanitation. 4th edn. Canada: John Wiley and Sons, pp: 44-45.

47. Pelczar MJ, Chan ECS, Krieg NR (1993) Microbiology, concepts and applications. New York: McGraw-Hill, USA, pp: 80-100, 158-161, 370. 